\title{
Nutrient limitation of primary producers affects planktivorous fish condition
}

\author{
Arne Michael Malzahn 1
}

Alfred Wegener Institute for Polar and Marine Research, Biologische Anstalt Helgoland, Ostkaje 1118, 27498

Helgoland, Germany

\section{Nicole Aberle}

Leibniz Institute of Marine Sciences at the University of Kiel (IFM-GEOMAR), Düsternbrooker Weg 20, 24105 Kiel, Germany; Alfred Wegener Institute for Polar and Marine Research, Biologische Anstalt Helgoland, Ostkaje 1118, 27498 Helgoland, Germany

\section{Catriona Clemmesen}

IFM-GEOMAR, Düsternbrooker Weg 20, 24105 Kiel, Germany

\section{Maarten Boersma}

Alfred Wegener Institute for Polar and Marine Research, Biologische Anstalt Helgoland, Ostkaje 1118, 27498 Helgoland, Germany; GKSS Research Centre, Institute for Coastal Research, Max-Planck-Strasse 1, 21502 Geesthacht, Germany

\begin{abstract}
We investigated whether nutrient limitations of primary producers act upward through food webs only in terms of density effects or if there is a second pathway for nutrient limitation signals channelled upward to higher trophic levels. We used tritrophic food chains to assess the effects of nutrient-limited phytoplankters (the cryptophyte Rhodomonas salina) on herbivorous zooplankters (the calanoid copepod Acartia tonsa) and finally zooplanktivores (larval herring Clupea harengus) living on the herbivores. The primary producers' food quality had a significant effect on fish condition. Our experimental phosphorus-limited food chain resulted in larval fish with a significantly poorer condition than their counterparts reared under nitrogen-limited or nutrient-sufficient conditions. Our results show that mineral nutrient requirements of consumers have to be satisfied first before fatty acids can promote further growth. This challenges the match/mismatch hypothesis, which links larval fish survival probability solely to prey availability, and could imply that reduced nutrient releases into the environment may affect fish stocks even more severely than previously believed.
\end{abstract}

Herbivores usually feed on low-quality food because the stoichiometry (i.e., the ratio of elements) of the plant diet differs strongly from the demand of the consumer (Sterner and Elser 2002). Plants generally contain relatively high concentrations of carbon and lower concentrations of other major elements such as nitrogen and phosphorus. Furthermore, the nutrient stoichiometry in many plants roughly reflects that of their surroundings. In contrast, most animals maintain a greater level of homeostasis (i.e., they keep a constant ratio of carbon to nutrients), and, hence, they have to deal not only with food of a constantly low quality but additionally with fluctuations in this quality.

One of the best-studied plant-herbivore interactions in aquatic environments is the interface between microalgae and zooplankton, but it remains unclear whether the

${ }^{1}$ Corresponding author (arne.malzahn@awi.de).

\section{Acknowledgments}

We thank Christoph Petereit, Daniela Harrer, Nicole Kube, and Michael Donner for the helping hands during the experiments and Helgi Mempel for his helpful assistance in the laboratory. This study was part of the Deutsche Forschungsgemeinschaftproject FRISCA (AB 289/1-1) and the Helgoland Foodweb Project. We are grateful for the funding. This study complies with the current German law on animal studies. changes in quality of phytoplankton as food for zooplankters are direct, i.e., nutrient limitations (Urabe et al. 1997; Boersma 2000; Plath and Boersma 2001), or whether accompanying changes, such as changes in the fatty acid spectrum (Müller-Navarra 1995), are responsible for the observed quality effects on consumers. Herbivores have several mechanisms to deal with excess carbon, such as respiring carbohydrates (Trier and Mattson 2003), thermogenesis (Zanotto et al. 1997; Raubenheimer and Simpson 2003), or adjusting digestion (Lee and Houston 1993; Sabat et al. 1999; Hilton et al. 2000). Zooplankters might react with an increase in appendage beat rate (Plath and Boersma 2001) or simply refuse to eat low-quality diets (Irigoien et al. 2005). Whatever the strategy might be, handling excess carbon creates costs, and these are usually compensated by decreased growth or reproduction (Boersma 2000; Boersma and Kreutzer 2002).

Herbivore homeostasis, combined with the regulatory mechanisms just described, has led to the commonly accepted assumption that quality effects in the herbivoreplant interface are not transported up the food chain, and the only important signal of variation in food quality to higher trophic levels is of a quantitative nature, as herbivores tend to grow and reproduce at lower rates under poor feeding conditions. Here, we challenge this 


\begin{tabular}{|c|c|c|c|c|c|c|}
\hline Trophic level & Experimental species & \multicolumn{4}{|c|}{ Treatment } & \\
\hline & & $\mathrm{f} / 2$ & $-\mathrm{P}$ & $-\mathrm{N}$ & no food & \\
\hline Phytoplankton & Rhodomonas salina & $\left.\right|_{\text {fed to }}$ & $\left.\right|_{\text {fed to }}$ & $\left.\right|_{\text {fed to }}$ & & $\begin{array}{l}\text {-each day new batch culture (20x) } \\
\text {-each culture grown for } 6 \text { days } \\
\text { (until limitation for -P and -N) }\end{array}$ \\
\hline Zooplankton & Acartia tonsa & $\sum_{1}^{\text {fed to }}$ & $\left.\right|_{\substack{1 \\
\text { fed to }}} ^{\mathbf{x}}$ & $\left.\right|_{1} ^{\mathbf{x}}$ & & $\begin{array}{l}\text {-each day new copepod cultures }(10 \mathrm{x}) \\
\text {-each culture grown for } 7 \text { days } \\
\text { (reared to } \mathrm{N} 5 / \mathrm{C} 1 \text { ) }\end{array}$ \\
\hline Fish & Clupea harengus & $\mathbf{x}$ & $\mathbf{x}$ & $\mathbf{x}$ & $\mathbf{x}$ & $\begin{array}{l}\text {-fed on experimental diets } 5 \text { days } \\
\text {-one non-fed control group }\end{array}$ \\
\hline
\end{tabular}

Fig. 1. Simplified illustration and main details of the experimental procedure. Numbers in brackets indicate the total number of cultures ran during experiments one and two.

assumption based on the following evidence: homeostasis of zooplankters is far from perfect, and within-species variation in carbon-to-nutrient ratios has been reported (Plath and Boersma 2001; Boersma and Kreutzer 2002). Consequently, their quality as food for their predators should vary. Furthermore, large interspecific variations have been reported for marine (Gismervik 1997) and freshwater zooplankters (Hessen 1992). Hence, given the argument of Brett (1993), which says that stoichiometric needs of secondary consumers and the stoichiometry of prey are normally finely tuned, this means that there is ample opportunity for quality differences between prey organisms of different nutritional status to be transferred to the next trophic level. Consequently, we do not expect that nutrient limitation of primary production would act only on higher trophic levels in terms of density effects. We therefore hypothesize that nutrient limitations can also act upward through the food web in the form of food-quality signals, and, hence, bottom-up control mechanisms are not only of a quantitative nature.

In order to test this hypothesis, we conducted two experiments to track the effects of nutrient limitation through a tritrophic food chain, from primary producers to primary and secondary consumers.

\section{Material and methods}

In order to investigate upward-travelling nutrient (nitrogen $[\mathrm{N}]$ and phosphorus $[\mathrm{P}]$, respectively in the following) effects through several trophic levels, algae, copepods, and larval herring were reared under three nutrient regimes (Fig. 1). To investigate the effect of food quality rather than food quantity, we adjusted the food fed to the two consumer levels to equal amounts for the three treatments.

Phytoplankton-A stock culture of Rhodomonas salina was cultivated in enriched seawater, following Guillard and Ryther (1962). For our experiments, we cultivated algae at $18^{\circ} \mathrm{C}$ under a $16: 8 \mathrm{~h}$ light : dark (LD) light regime in enriched natural seawater (salinity $\sim 15$ ), as well as under nutrient (here, $\mathrm{P}$ and $\mathrm{N}$ ) limitation. Prior to the experiment, all of the water used for algae cultures during the experiments was filtered using a $0.2-\mu \mathrm{m}$ sterile filter in one effort and stored cool and dark until use. The first treatment consisted of $\mathrm{f} / 2$-enriched seawater ( $\mathrm{f} / 2$ contains $8.83 \quad 10^{-4} \mathrm{~mol} \mathrm{~L}^{-1} \quad \mathrm{NaNO}_{3}$ and $3.63 \quad 10^{-5} \mathrm{~mol} \mathrm{~L}^{-1}$ $\mathrm{NaH}_{2} \mathrm{PO}_{4}$ ), as described by Guillard and Ryther (1962). The algae of the two limitation treatments were also enriched after Guillard and Ryther (1962), but without the addition of the limiting nutrient (no $\mathrm{P}$ or $\mathrm{N}$ addition; $-\mathrm{P}$ and $-\mathrm{N}$ in the following), so they could therefore only utilize the natural $\mathrm{P}$ or $\mathrm{N}$ sources present in the seawater at the moment of filtration. This kind of enrichment ensured a limitation of the desired nutrient by enriching the media with the other nutrients (i.e., $\mathrm{N}$ or $\mathrm{P}$, vitamins, and metals) in excess. Several tests on algal growth rates were conducted prior to the experiments to detect the "carrying capacity" of the three different media and to define the duration until the algae were properly limited by the element of choice in the different treatments. Concentrations of algae were determined using fluorometric measurements (Turner, 10-AU-005-CE) at an excitation wavelength of $436 \mathrm{~nm}$ and an emission wavelength of $680 \mathrm{~nm}$. Prior to the experiments, individual cell number-fluorescence relationships were set up using flow cytometer counts at seven concentrations ranging from 0.05 to $1.7 \times$ $10^{6}$ cells $\mathrm{mL}^{-1}$ for all three differently grown algae.

To ensure constant food quality, new cultures of each of the treatments were inoculated every day with roughly 0.2 $\times 10^{6}$ cells $\mathrm{mL}^{-1}$ for the $-\mathrm{N}$ treatment and $0.3 \times 10^{6}$ for the $-\mathrm{P}$ and $\mathrm{f} / 2$ treatments. Algae were harvested at densities of $\sim 0.5,1.0$, and $1.3 \times 10^{6}$ cells $\mathrm{mL}^{-1}(-\mathrm{N}$, $-\mathrm{P}$, and $\mathrm{f} / 2$, respectively) after the predefined growth phase of six days for $-\mathrm{N}$ and seven days for $\mathrm{f} / 2$ and $-\mathrm{P}$. These were the maximum densities possible with the natural $\mathrm{N}$ or $\mathrm{P}$ sources contained in the seawater. To prevent foodquantity effects, the copepods were fed with the same amount of algal cells at each treatment.

Zooplankton-Eggs of the calanoid copepod Acartia tonsa were produced in 200-liter cylindrical tanks, where the animals were cultivated at $18^{\circ} \mathrm{C}$ at a $12: 12 \mathrm{LD}$ cycle. Copepods were fed on a mixture of the algae Rhodomonas salina, Dunaliella sp., and the flagellate Oxhyrris sp. Eggs were siphoned from the bottom of the tanks daily and 
stored in seawater at $4^{\circ} \mathrm{C}$ for later use. No eggs older than three months were used during the experiments.

The stored eggs were incubated in fresh seawater. The hatch rate of the eggs was around $20 \%$. The copepods used for the experiments were reared from the egg to the fifth naupliar stage in 5-liter plastic bags at $18^{\circ} \mathrm{C}$ at densities of 1,500 individuals $\mathrm{L}^{-1}$. The cultured algae were fed to the copepods at $\sim 1.0 \mathrm{mg}$ carbon $\mathrm{L}^{-1} \mathrm{~d}^{-1}$ for five consecutive days. In order to guarantee that the algal deficiencies were not changed by uptake of nutrients during the incubations with the copepods, the copepods were reared in artificial, $\mathrm{N}$ - and P-free seawater that was adjusted to a salinity of 18 (salt: hw-Marinemix, www.hw-wiegandt.de). Copepods were first fed $48 \mathrm{~h}$ after addition of the eggs to the rearing bags, assuming two days for the development from the egg to the first feeding second naupliar stage. For each day of the feeding experiment, three new copepod bags (one for each treatment) were started to ensure a constant food quality for the secondary consumers, the larval herring Clupea harengus. Copepods were harvested after seven days of cultivation when $\sim 80 \%$ of all the animals were in their fifth naupliar stage and $\sim 20 \%$ were in the fourth. These copepods were then fed to the larval herring at densities of 1 individual $\mathrm{mL}^{-1}$ for all treatments.

Fish-Herring larvae were obtained by means of artificial fertilization. Adult ripe Baltic herring Clupea harengus were purchased from a local fisherman. The fish were transported immediately to the laboratory and kept on ice the whole time. Female fish were strip-spawned on glass plates. The eggs were applied in single rows to ensure a good oxygen supply during the incubation phase, and the glass plates were placed in a plastic box. Milt was stripped onto the eggs and activated by the addition of seawater. Fertilization was allowed to take place for five minutes; afterward, the eggs were washed and transferred to the incubation containers. Eggs were incubated in a flowthrough system, using $4-\mu \mathrm{m}$ prefiltered natural seawater at $13^{\circ} \mathrm{C}$. The first hatch took place on the night of day 10 ; peak hatch took place the following night. Only larvae from the hatch peak were used during the experiments. Larvae were transferred to cylindrical 200-liter stock tanks. The stock tanks were operated as a flow-through system and gently supplied with prefiltered water. Experiment one was started using 4-d-posthatch larvae, which had no feeding experience. The larvae in the stock tanks were fed from day 4 on the rotifer Brachionus plicatilis reared on the algae Nannochloropsis sp. B. plicatilis were taken from routine cultures of the facility. Experiment two was started using 9-d-posthatch larvae.

Twenty larvae each were randomly transferred to 1-liter glass beakers filled with GF/F filtered seawater. The four treatments $(-\mathrm{P},-\mathrm{N}, \mathrm{f} / 2$, and starving) were replicated 10 times (with 20 larvae each) in experiment one and three times in experiment two. Both experiments were conducted at $15^{\circ} \mathrm{C}$, and larval herring were reared for six days. Within the six days, larvae were fed the quality-manipulated diets five times. Feeding took place at noon. The food quantity fed to the herring was kept constant between the treatments and over the experimental period ( 1 copepod $\left.\mathrm{mL}^{-1} \mathrm{~d}^{-1}\right)$.
This prey concentration is higher than the densities that are usually reported for food-saturated growth in larval herring (Clemmesen 1994). This was corroborated by the fact that in all of the experimental containers, copepods were still present after one day of feeding. More than $80 \%$ of the water was replaced daily before feeding to ensure that the vast majority of uneaten prey organisms stayed in the experimental container for a maximum of $24 \mathrm{~h}$. This was essential in order to avoid alterations of the body composition of the copepods due to starvation and hence to assure a constant food quality over the experimental period. The experiments were terminated on the morning after the fifth day of herring feeding.

Analytical procedures-The nutritional condition of larval herring was assessed by means of the analysis of the ratio between ribonucleic acid (RNA) and deoxyribonucleic acid (DNA) content in the organisms, a method commonly used in larval fish ecology and fisheries research. The analysis of RNA and DNA concentrations of individual herring larvae was performed using a modification of the method by Clemmesen (1993). Larval herring were thawed, and standard length was measured using a stereomicroscope. Larvae were freeze-dried to constant weight (16 h, using a Christ Alpha 1-4 freeze-dryer at $-51^{\circ} \mathrm{C}$ ) and were weighed to the nearest $0.0001 \mathrm{mg}$ (Sartorius microbalance SC2). The freeze-dried larvae were rehydrated in Tris-SDS buffer (Tris $0.05 \mathrm{~mol} \mathrm{~L}^{-1}, \mathrm{NaCl} 0.01 \mathrm{~mol} \mathrm{~L}^{-1}$, ethylenediaminetetracetic acid (EDTA) $0.01 \mathrm{~mol} \mathrm{~L}^{-1}$, sodium dodecyl sulfate (SDS) $0.01 \%$ ) for $15 \mathrm{~min}$. Cells were disrupted by shaking in a cell-mill with different-sized glass beads (diameter $2.0 \mathrm{~mm}$ and $0.17-0.34 \mathrm{~mm}$ ) for $15 \mathrm{~min}$. The homogenate was then centrifuged at $6,000 \mathrm{rpm}$ at $0^{\circ} \mathrm{C}$ for $8 \mathrm{~min}$, and the supernatant was used for the analysis. The amount of nucleic acids was measured fluorometrically in a microtiter fluorescence reader (Labsystems, Fluorescan Ascent) using the fluorophor ethidiumbromide. Total nucleic acids were measured first, and, subsequently, RNAse was applied to the sample in order to digest the RNA. After the enzyme treatment $\left(30 \mathrm{~min}\right.$ at $\left.37^{\circ} \mathrm{C}\right)$, the remaining DNA was measured. The RNA fluorescence was calculated by subtracting the DNA fluorescence from the total nucleic acid fluorescence. RNA calibrations were set up every measurement day. The DNA concentrations were calculated using the relationship between RNA and DNA fluorescence described by Le Pecq and Paoletti (1966).

For the analysis of carbon and nitrogen contents of the algae, an estimated amount of $150 \mu \mathrm{g}$ algal carbon was filtered on precombusted Whatman GF/F filters. For the analysis of copepod carbon and nitrogen, 500 individuals were counted into tin capsules. The elemental analyses were done using a Fison 1500N CHN analyzer. Phosphorus was analyzed as orthophosphate after acidic oxidative hydrolysis with $5 \% \mathrm{H}_{2} \mathrm{SO}_{4}$ (Grasshoff et al. 1999). Unfortunately, algae $\mathrm{P}$ data are only available for experiment 1 . C:N, $\mathrm{C}: \mathrm{P}$, and $\mathrm{N}: \mathrm{P}$ ratios are given as the molar ratio.

The fatty acids of algae and copepods were measured as fatty acid methyl esters (FAMEs). Lipids were extracted from the samples by dichloromethane:methanol $(2: 1$ $\mathrm{vol}$ : vol) in an ultrasound bath for $30 \mathrm{~min}$. Water-soluble 
fractions were removed after centrifugation by washing with $0.88 \% \mathrm{KCl}$ buffer. The water phase was removed, and the organic remainder was evaporated using nitrogen gas. The esterification was done using methanolic sulfuric acid at $70^{\circ} \mathrm{C}$ for $30 \mathrm{~min}$. The FAMEs were washed from the methanolic sulfuric acid using n-Hexane. Excess n-Hexane was evaporated using nitrogen gas. All chemicals used were suprasolv or gas chromatography (GC) grade. FAMEs were analyzed by gas chromatography using a Varian CP 8400 gas chromatograph equipped with a DB-225 column (J\&W Scientific, 30-m length, 0.25-mm inner diameter [ID], $0.25-\mu \mathrm{m}$ film). The injector temperature was set to $250^{\circ} \mathrm{C}$. The column oven was set to $60^{\circ} \mathrm{C}$, which was held for $1 \mathrm{~min}$ after injection. The oven was heated to $150^{\circ} \mathrm{C}$ at $15^{\circ} \mathrm{C} \mathrm{min}-1$, then to $170^{\circ} \mathrm{C}$ at $3^{\circ} \mathrm{C} \mathrm{min}^{-1}$, and finally to $220^{\circ} \mathrm{C}$ at $1^{\circ} \mathrm{C} \mathrm{min}-1$, which was held for $21 \mathrm{~min}$. The carrier gas was helium at a constant pressure of $82.737 \mathrm{~Pa}$. The flame ionization detector was set to $300^{\circ} \mathrm{C}$. Injection of the $1-\mu \mathrm{L}$ aliquots of the samples was done in a split-less mode. FAMEs were quantified using calibrations set up for each fatty acid separately and a known amount of C 23:0 was added at the first step of the preparation as an internal standard.

Statistics-Fish standard length, dry weight, and RNA : DNA ratios were statistically analyzed by means of a two-factorial analysis of variance (ANOVA) with treatment and experiment as independent variables and RNA : DNA ratio as the dependent variable. Phytoplankton and zooplankton fatty acids, and $\mathrm{C}: \mathrm{P}, \mathrm{C}: \mathrm{N}$, and $\mathrm{N}: \mathrm{P}$ ratios were analyzed by one-factorial ANOVA, using treatment as the independent factor and the various fatty acid proxies or the nutrient ratios as the dependent variables. Phytoplankton $\mathrm{C}: \mathrm{N}$ was analyzed in a twofactorial ANOVA, using experiment and treatment as the independent factors and the $\mathrm{C}: \mathrm{N}$ ratio as the dependent variable. Due to the lack of phytoplankton $\mathrm{P}$ data for experiment two, phytoplankton $\mathrm{C}: \mathrm{P}$ and $\mathrm{N}: \mathrm{P}$ ratios were analyzed by a one-factorial ANOVA, using treatment as the independent factor and $\mathrm{C}: \mathrm{P}$ or $\mathrm{N}: \mathrm{P}$ as the dependent variable. Stoichiometric measures of zooplankton were analyzed in a two-factorial ANOVA, using experiment and treatment as independent factors and the stoichiometric measures as dependent variables. Phytoplankton and zooplankton fatty acid measures were analyzed by means of one-factorial ANOVA. Fish response variables to the different treatments (RNA:DNA, final standard length, and final dry weight) were analyzed in a two-factorial design with experiment and treatment as independent factors and the fishes' RNA: DNA ratio, standard length, and dry weight as the dependent variables. Duncan's tests were used as post-hoc tests in all cases.

\section{Results}

Phytoplankton-Algal molar $\mathrm{C}: \mathrm{N}$ ratios differed significantly between treatments in both experiments. We were able to create similar values in both experimental runs, so that the factor "Experiment" had no significant influence in the two-way ANOVA. Algae grown under $\mathrm{N}$ limitation showed the highest $\mathrm{C}: \mathrm{N}$ ratios, while $\mathrm{f} / 2$ and $\mathrm{P}$-limited algae showed significantly lower $\mathrm{C}: \mathrm{N}$ ratios $(\sim 10, \sim 7.5$, and $\sim 8.0$ respectively; $p<0.05$, Fig. $2 \mathrm{~A}$ ). Due to the lack of $\mathrm{P}$ data for experiment two, we were not able to investigate the effect of the experimental run. However, the $\mathrm{C}: \mathrm{P}$ ratio differed significantly among treatments ( $\mathrm{f} / 2$ $\sim 230,-\mathrm{N} \sim 180$, and $-\mathrm{P} \sim 580$; Fig. $2 \mathrm{~B}$ ). The same pattern was found in the $\mathrm{N}: \mathrm{P}$ ratio, where the P-limited treatment showed the highest value, and the $\mathrm{N}$-limited treatment showed the lowest values ( $\mathrm{f} / 2 \sim 25,-\mathrm{N} \sim 15$, and $-\mathrm{P} \sim 78$; Fig. 2C).

The different nutrient-limitation treatments caused different fatty acid spectra in the algae (Table 1; Fig. 3A). The $-\mathrm{P}$ treatment showed not only the highest concentra-

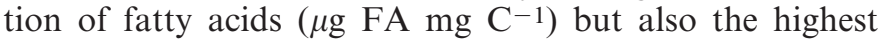
amount and proportion of unsaturated fatty acids, omega3 , and omega- 6 fatty acid concentrations, as well as the lowest percentage of saturated fatty acids in the experiment (all $p<0.05$ to $\mathrm{f} / 2$ and no differences compared to $-\mathrm{N})$.

Zooplankton-Copepod $\mathrm{C}: \mathrm{N}$ ratios showed significant differences among treatments. In experiment one, copepods that were fed on $\mathrm{N}$ - as well as P-limited algae showed significantly higher $\mathrm{C}: \mathrm{N}$ ratios in comparison with those copepods fed on nonlimited algae. In experiment two, no differences where found due to the unexpectedly low $\mathrm{C}: \mathrm{N}$ ratios in the N-limited treatment (Fig. 2A). Significantly different $\mathrm{C}: \mathrm{P}$ ratios in zooplankton were created by the different phytoplankton diet ( $\mathrm{f} / 2 \sim 180,-\mathrm{N} \sim 186$, and $-\mathrm{P}$ $\sim 280$ ). The $-\mathrm{P}$ treatment created significantly higher $\mathrm{C}: \mathrm{P}$ and $\mathrm{N}: \mathrm{P}$ ratios in copepods than the $\mathrm{f} / 2$ and the $-\mathrm{N}$ treatments did (both $p<0.01$ ). The latter two did not differ significantly (Fig. 2B). Exactly the same pattern in fatty acid measures was found for zooplankton reared on different algae treatments as in phytoplankton (Table 1; Fig. 3B). The $-\mathrm{P}$ treatment showed not only the highest

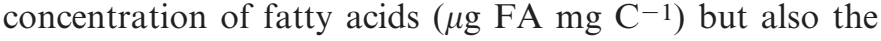
highest amount and proportion of unsaturated fatty acids, omega-3, and omega- 6 fatty acid concentrations, as well as the lowest percentage of saturated fatty acids in the experiments (all $p<0.05$ to $\mathrm{f} / 2$ and no differences compared to $-\mathrm{N}$ ). This implies that for both the copepods as well as the fish, the best food quality in terms of fatty acids was produced under $\mathrm{P}$ limitation, followed by the Nlimited conditions. The f/2-cultivated phytoplankton seemed to be of the poorest food quality when only fatty acid spectra were considered. On the other hand, in nutrient stoichiometric terms, f/2 produced the highest food quality (lowest $\mathrm{C}: \mathrm{N}$ and $\mathrm{C}: \mathrm{P}$ ratios), and the limitations created food of much lower (i.e., higher $\mathrm{C}: \mathrm{P}$ and $\mathrm{C}: \mathrm{N}$ ratios) quality. This opposing effect enabled us to distinguish differential effects of nutrient- and biochemicaloriginated food quality.

Fish - The age of the larvae had a significant effect on the RNA : DNA ratio, where older larva showed generally a better condition (Table 2). For young larvae (experiment one), no significant differences among the treatments were detected. All fed treatments showed significantly different 

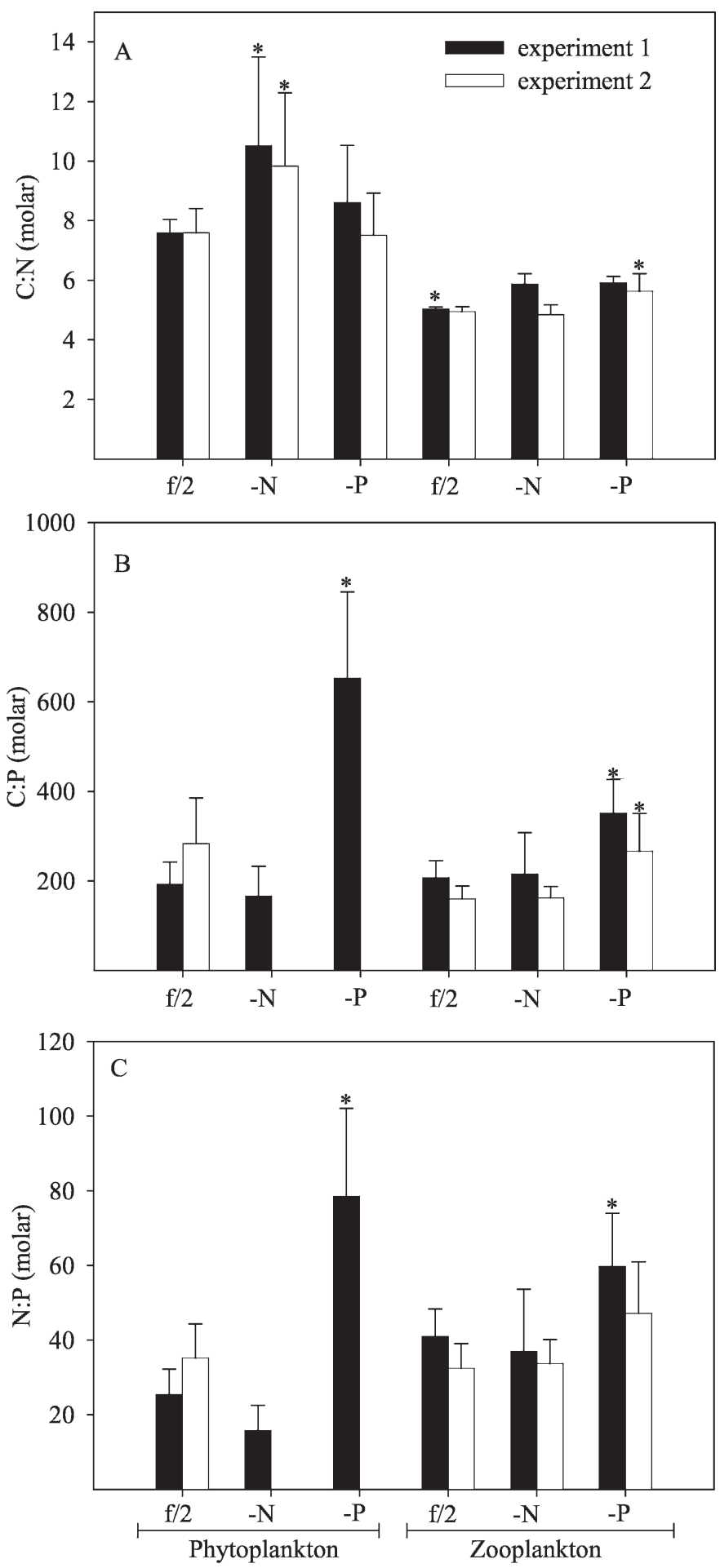

Fig. 2. (A) Molar $\mathrm{C}: \mathrm{N}$, (B) $\mathrm{C}: \mathrm{P}$, and (C) $\mathrm{N}: \mathrm{P}$ ratios of phytoplankton cultured under nutrient-sufficient (f/2), N-limited $(-\mathrm{N})$, and P-limited $(-\mathrm{P})$ conditions and the molar $(\mathrm{A}) \mathrm{C}: \mathrm{N},(\mathrm{B})$ $\mathrm{C}: \mathrm{P}$, and $(\mathrm{C}) \mathrm{N}: \mathrm{P}$ ratios of the zooplankton reared on the different phytoplankton cultures. Error bars: 1 standard deviation. Asterisk marks significant differences $(p<0.05)$ from the other treatments of the given species and experiment.
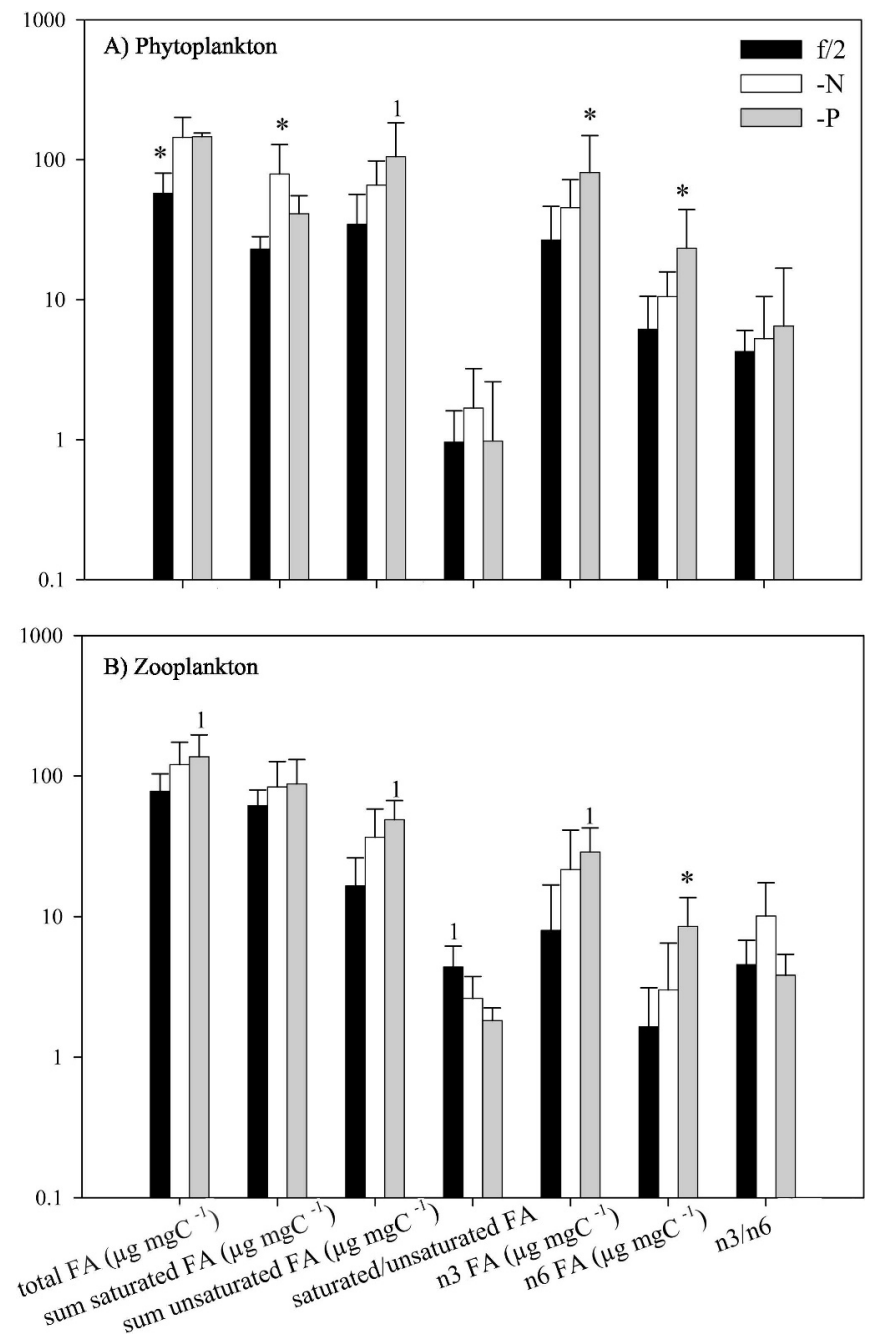

Fig. 3. Summary of several fatty acid proxies of (A) phytoplankton cultured under nutrient-sufficient ( $\mathrm{f} / 2), \mathrm{N}$-limited $(-\mathrm{N})$, and P-limited $(-\mathrm{P})$ conditions and $(\mathrm{B})$ zooplankton reared on the different phytoplankton cultures. Error bars: 1 standard deviation. Asterisk marks significant differences $(p<0.05)$ from the other treatments, and " 1 " marks significant differences between $-\mathrm{P}$ and $\mathrm{f} / 2$ only.

values than the starved larvae of experiment one. Older larvae of experiment two showed the same pattern as those of experiment one, but these patterns were more pronounced, and differences were significant, despite the lower level of replication. All fed treatments differed significantly in their RNA: DNA ratios from each other (Duncan's test $p<0.05$ ). The $\mathrm{N}$-limited treatment showed the highest RNA:DNA ratios, followed by the $f / 2$ treatment. The $-\mathrm{P}$ treatment showed the poorest nutritional condition of the fed groups. All three fed treatments differed significantly from the corresponding food-deprived groups (Fig. 4A). Growth virtually provided the same pattern at either the final standard length (Fig. 4B) or the final dry weight (Fig. 4C) of the larval herring. Again, the N-limited food chain produced the longest and heaviest larvae, followed by the $\mathrm{f} / 2$ and the $-\mathrm{P}$ treatment 


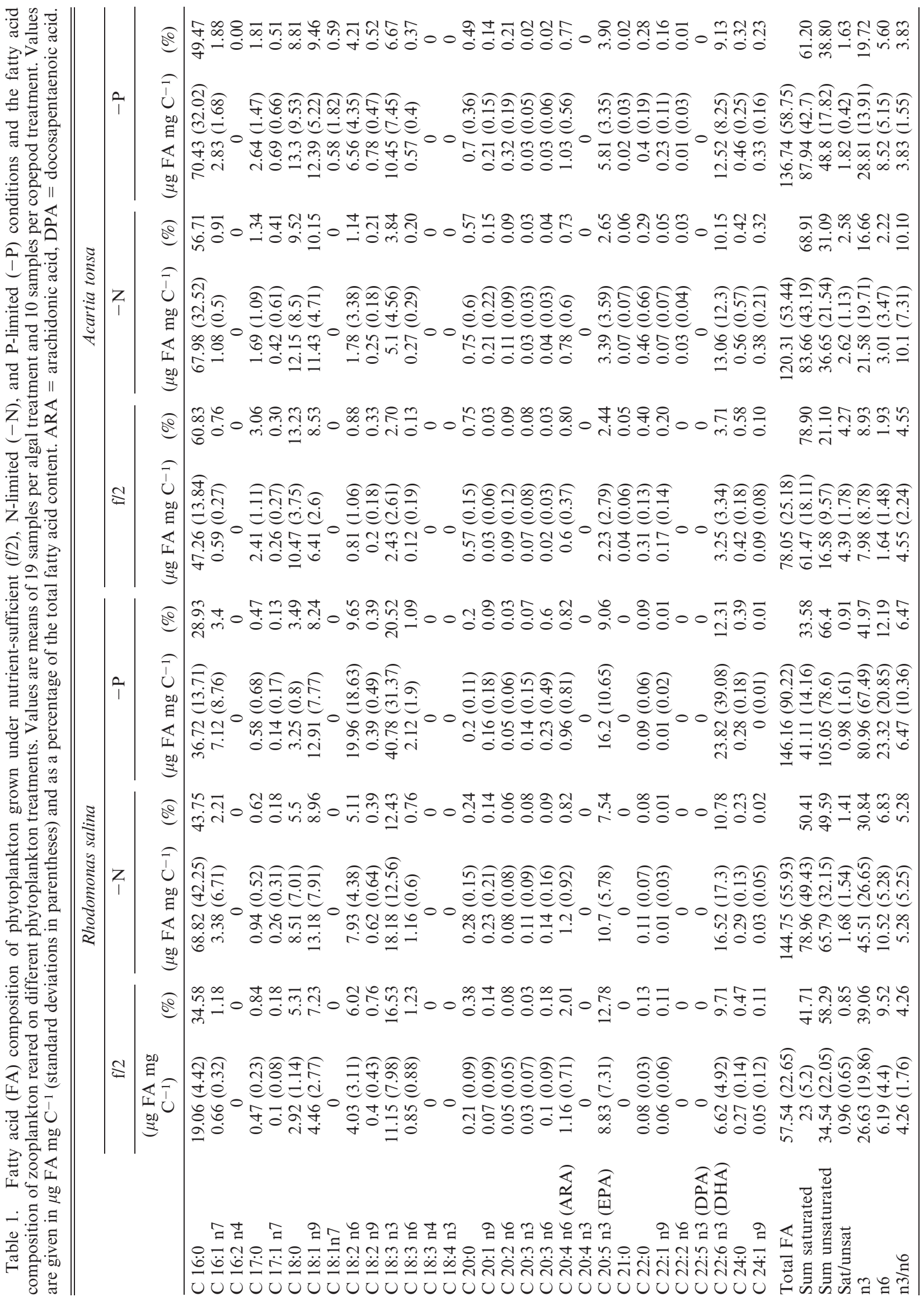


Table 2. Summary of all analyses of variance (ANOVA). Phytoplankton C: N was analyzed in a two-factorial ANOVA, using experiment and treatment as independent factors and the $\mathrm{C}: \mathrm{N}$ ratio as dependent variable. Phytoplankton $\mathrm{C}: \mathrm{P}$ and $\mathrm{N}: \mathrm{P}$ were analyzed by a one-factorial ANOVA, using treatment as the independent factor and $\mathrm{C}: \mathrm{P}$ or $\mathrm{N}: \mathrm{P}$ as the dependent variable. Stoichiometric measures of zooplankton were analyzed in a two-factorial ANOVA, using experiment and treatment as independent factors and the stoichiometric measures as dependent variables. Fish data were analyzed in a two-factorial design with experiment and treatment as independent factors and the fishes RNA : DNA ratio, standard length, and dry weight as dependent variables.

\begin{tabular}{|c|c|c|c|c|c|c|}
\hline Trophic level & Factor & & MS & $\mathrm{df}$ & $F$ & $p$ \\
\hline \multirow[t]{8}{*}{ Phytoplankton } & $\mathrm{C}: \mathrm{N}$ & Experiment & 10.175 & 1 & 3.726 & n.s. \\
\hline & & Treatment & 58.681 & 2 & 21.491 & $<0.01$ \\
\hline & & Exp. x Treat. & 2.094 & 2 & 0.767 & n.s. \\
\hline & & Error & 2.731 & 73 & & \\
\hline & $\mathrm{C}: \mathrm{P}$ & Treatment & 591,618 & 2 & 41.0142 & $<0.01$ \\
\hline & & Error & 14,425 & 27 & & \\
\hline & $\mathrm{N}: \mathrm{P}$ & Treatment & $9,018.76$ & 2 & 46.0649 & $<0.01$ \\
\hline & & Error & 195.78 & 27 & & \\
\hline \multirow[t]{12}{*}{ Zooplankton } & $\mathrm{C}: \mathrm{N}$ & Experiment & 1.4003 & 1 & 11.667 & $<0.01$ \\
\hline & & Treatment & 1.2187 & 2 & 10.154 & $<0.01$ \\
\hline & & Exp. x Treat. & 0.5320 & 2 & 4.433 & $<0.05$ \\
\hline & & Error & 0.1200 & 20 & & \\
\hline & $\mathrm{C}: \mathrm{P}$ & Experiment & 24,045 & 1 & 6.3839 & $<0.05$ \\
\hline & & Treatment & 39,732 & 2 & 10.5489 & $<0.01$ \\
\hline & & Exp. x Treat. & 841 & 2 & 0.2233 & n.s. \\
\hline & & Error & 3,766 & 20 & & \\
\hline & $\mathrm{N}: \mathrm{P}$ & Experiment & 414.23 & 1 & 3.3791 & n.s. \\
\hline & & Treatment & 800.12 & 2 & 6.5269 & $<0.01$ \\
\hline & & Exp. x Treat. & 45.21 & 2 & 0.3688 & n.s. \\
\hline & & Error & 122.59 & 20 & & \\
\hline \multirow[t]{12}{*}{ Fish } & RNA : DNA & Experiment & 0.57254 & 1 & 16.8299 & $<0.01$ \\
\hline & & Treatment & 0.54261 & 3 & 15.9501 & $<0.01$ \\
\hline & & Exp. x Treat. & 0.20525 & 3 & 6.0332 & $<0.01$ \\
\hline & & Error & 0.03402 & 44 & & \\
\hline & Standard length & Experiment & 15.945 & 1 & 144.73 & $<0.01$ \\
\hline & & Treatment & 1.516 & 3 & 13.76 & $<0.01$ \\
\hline & & Exp. x Treat. & 0.708 & 3 & 6.42 & $<0.01$ \\
\hline & & Error & 0.110 & 44 & & \\
\hline & Dry weight & Experiment & $12,961.0$ & 1 & 230.427 & $<0.01$ \\
\hline & & Treatment & $3,190.3$ & 3 & 56.718 & $<0.01$ \\
\hline & & Exp. x Treat. & $1,559.7$ & 3 & 27.729 & $<0.05$ \\
\hline & & Error & 56.2 & 44 & & \\
\hline
\end{tabular}

(Table 2). All differences in weight and length were significant.

\section{Discussion}

We hypothesized that nutrient limitation acts upward through the food web in the form of food-quality signals, and, hence, bottom-up control mechanisms are not only of a quantitative nature. Our results support this hypothesis, as nutrient-limitation signals from phytoplankters were transferred via zooplankters to secondary consumers, despite the fact that larval fish were fed ad libitum, and, thus, density-dependent prey effects were excluded. The copepods in our experiments clearly dampened the variation of carbon: nutrient ratios of their food, but only to a certain degree. Hence, zooplankton homeostasis should be regarded as relaxed in nature rather than strict (Plath and Boersma 2001; Boersma and Kreutzer 2002). This relaxed homeostasis led to limited growth of secondary consumers, in our case larval herring.
Phytoplankton-In our study, the cryptophyte Rhodomonas salina produced significantly more total fatty acids and unsaturated fatty acids, such as ecosapentaenoic acid (20:5n3, EPA) and docosahexaenoic acid (22:6 n3, DHA), under both $\mathrm{N}$ and $\mathrm{P}$ limitation, and thus in our case, the limited algae showed enhanced food quality compared with the algae grown under excess nutrient conditions with respect to the fatty acid composition. Nutrient limitation is known to be reflected in alterations of algal biochemistry. Typically, under $\mathrm{N}$ limitation, the protein content of algae is reduced, while under $\mathrm{P}$ limitation, phospholipids concentration is lower (Klausmeier et al. 2004). The total lipid content seems to be positively affected by nutrientlimiting growth conditions, although there are large interspecific variations (Sterner and Hessen 1994). The enhanced lipid levels of the nutrient-limited algae altered the carbon: nutrient ratios of the limited phytoplankton to higher carbon: nutrient ratios, and as a result, from a nutrient point of view, these phytoplankters must be considered as food of lower quality for consumers (Sterner and Elser 2002). 

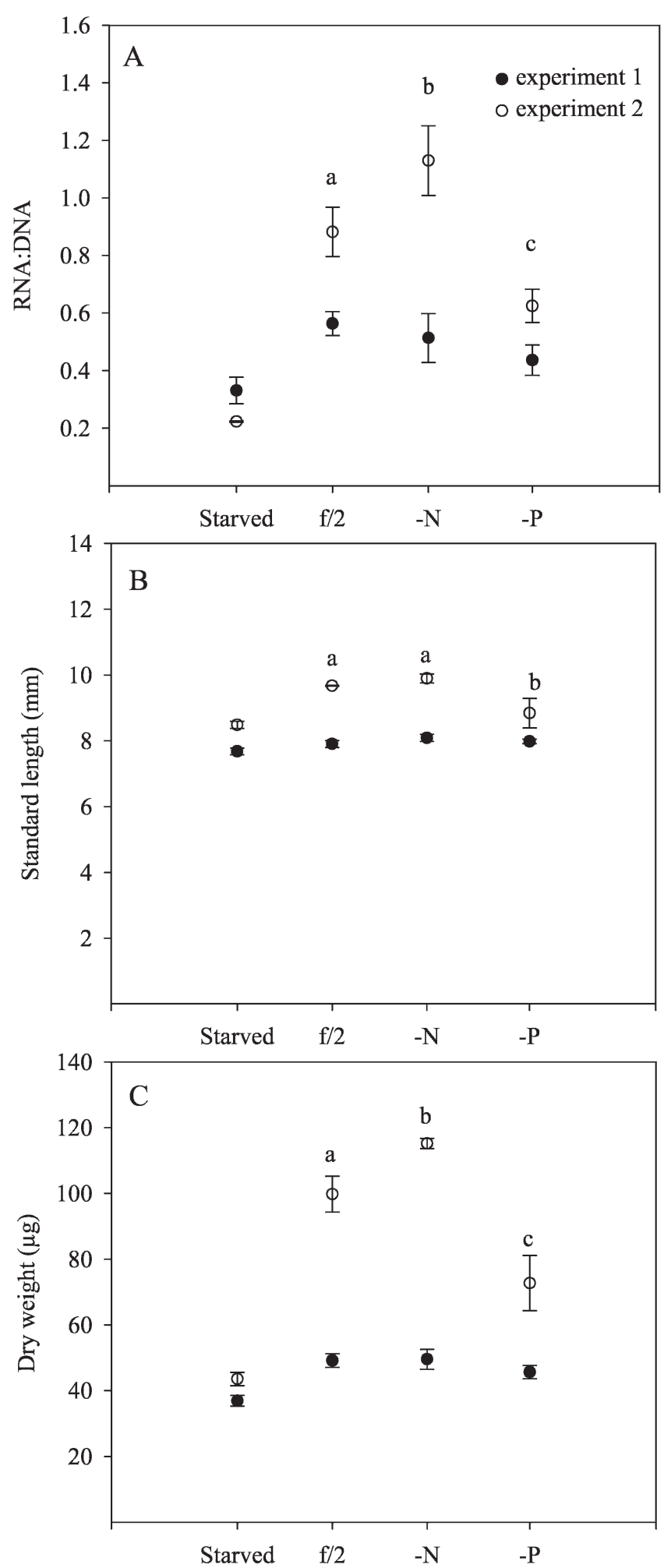

Treatment

Fig. 4. Response variables of larval fish reared on zooplankton that was fed on phytoplankton cultured under nutrientsufficient ( $\mathrm{f} / 2)$, N-limited $(-\mathrm{N})$, and P-limited $(-\mathrm{P})$ conditions. (A) RNA : DNA ratio, (B) larval standard length (mm), and (C) larval dry weight $(\mu \mathrm{g})$. Error bars: 1 standard deviation. Significant differences $(p<0.05)$ between treatments are indicated
Zooplankton-Long-chained, unsaturated fatty acids like EPA and DHA cannot be synthesized de novo by most copepods and, hence, have to be taken up in the food. Consequently, the copepod fatty acid compositions reflected those of their diets well, a pattern which is in good correspondence with previous studies (Sargent and FalkPetersen 1988). The copepods reared on P-limited algae represented the best food offered to larval herring in terms of fatty acids. We found significantly higher $\mathrm{C}: \mathrm{P}$ ratios in copepods grown on P-limited algae but unaffected $\mathrm{C}: \mathrm{N}$ ratios of copepods grown on N-limited algae. Similar findings of upward-travelling effects of nutrient-limited phytoplankton have been reported by Sterner (1993), DeMott et al. (1998), and Plath and Boersma (2001), but, to our knowledge, no one has made the next step and investigated the effects of a relaxed homeostasis of zooplankters on growth of those who feed on the zooplankters.

Fish-The RNA:DNA ratio is a valid predictor for nutritional condition of larval fish. This has been validated in many laboratory and field studies (Clemmesen 1994; Malzahn et al. 2003, in press). The RNA:DNA ratio of larval herring in our first experiment showed no significant differences between the fed groups, but significant differences were observed between all fed groups and the starvation control. These observations could be attributed to the simultaneous exploitation of internal (yolk) and external energy sources (copepods). Suneetha et al. (1999) also reported less serious starvation effects in smaller herring larvae (Clupea harengus) than in bigger ones and attributed this finding to benefits derived from leftover yolk. In older herring, which were exclusively dependent on external energy sources, the $\mathrm{N}$-limited food chain produced the best conditioned larvae. This is contrary to the predictions that could be drawn from the fatty acid profiles alone, where the P-limited food chain displayed the best food quality. High levels of fatty acids are known to favor growth in larval fish. St. John et al. (2001) were able to demonstrate significant effects of dietary EPA as well as DHA levels on larval cod growth, and Izquierdo et al. (2000) stressed not only the major role of high fatty acid concentrations but also the importance of ratios between certain fatty acids for the growth of larval fish. Nevertheless, the herring larvae reared under the highest lipid supply showed the lowest nutritional condition. Under the assumption that the same processes are acting not only at the primary producer-herbivore interface but also at interfaces between higher trophic levels, this could well be attributed to the unfavorable high $\mathrm{C}: \mathrm{P}$ ratio of the zooplankters of the P-limited food chain. This inevitably leads to the conclusion that the herring's growth was P-

$\leftarrow$

with different letters for experiment two. In both experiments, RNA : DNA ratios of all fed treatments were significant different $(p<0.05)$ from the corresponding starving group. No differences within experiment one were present in standard length and dry weight. 
limited. Considering the best herring growth performance reared on the $\mathrm{N}$-limited food chain, the $\mathrm{C}: \mathrm{P}$ ratio and the lipid measures suggest that biochemical components like fatty acids can further promote growth, provided that nutrient requirements are satisfied.

Further support for the notion that fish growth can be Plimited is derived from aquaculture studies (e.g., Vielma et al. 2002), which have shown that it is quite possible for growth in fish to be limited by a shortage in P supply. In fact, the study by Boersma and Elser (2006) summarized many findings stating that secondary production typically reaches a maximum when the $\mathrm{P}$ content of the food is around $0.5-1.0 \%$ of dry weight. This translates to a molar $\mathrm{C}: \mathrm{P}$ ratio of $125-250$ (assuming $\mathrm{C}$ is $50 \%$ of dry weight), above which secondary production is limited by P. In our study, the $\mathrm{C}: \mathrm{P}$ ratio of the P-limited copepods was well above 300; therefore, $\mathrm{P}$ limitation for the fish was very likely. Despite this fact, almost no studies exist that investigate this in an ecological context (but see Hood et al. 2005). Schindler and Eby (1997) demonstrated the possibility of $\mathrm{P}$ limitation on fish growth rates by means of model exercises. P-limited growth rates were presented for 3 out of 186 cases, while another 5 cases where probably close to limitation. The three cases they reported were for zooplanktivorous fish, where limitation of primary production is more likely to have an effect than in benthic food webs. Contrasting to the dominant P-rich cladocerans in freshwater systems, marine systems are dominated mainly by copepods, which have a much higher $\mathrm{N}: \mathrm{P}$ ratio than cladocerans ( 50 for calanoid copepods and 15 for Daphnia; Elser et al. 1996). In terms of P content, planktivorous fish in marine systems like herring should therefore more regularly face food of lower quality (in terms of P) than their freshwater relatives are. Schindler and Eby's models (Schindler and Eby 1997) (and others) assume homeostasis in fish body nutrients. However, it is likely that larval fish body nutrient content is not homeostatic, especially for $\mathrm{P}$, due to strong ontogenetic shifts like the shift from predominantly muscle growth to the additional development of bones and fin rays later in the larval development, which have increasing $\mathrm{P}$ demands. This implies that there are phases in a fish's life that are more vulnerable to $\mathrm{P}$ limitation. Similar processes have been shown for daphnids, where differing $\mathrm{P}$ demands occur in young and older daphnids, suggesting nonhomeostatic body composition between ontogenetic stages also for zooplankters (Boersma 2000).

In summary, we found that nutrient-limitation signals can travel up the food chain, not only as a decreased quantity of the food (zooplankton) for secondary producers, but also the quality of the zooplankton as food for fish can change. This finding may have implications for the predictions of fish population dynamics. Larval fish might have lower growth rates than the actual prey availability would suggest, especially in situations where nutrients are limited, such as at the end of a phytoplankton bloom. Hence, larval fish growth in the field is not likely to be limited by food quantity only, but also by food quality, and it could well be that given the current re-oligotrophication in many systems, these effects will become stronger in years to come. When considering match-mismatch situations between predators and their prey, such quality-related effects should be attended more specifically in future studies.

\section{References}

Boersma, M. 2000. The nutritional quality of P-limited algae for Daphnia. Limnol. Oceanogr. 45: 1157-1161.

— AND J. J. Elser. 2006. Too much of a good thing: On stoichiometrically balanced diets and maximal growth. Ecology 87: 1325-1330.

—, AND C. KReutzer. 2002. Life at the edge: Is food quality really of minor importance at low quantities? Ecology 83: 2552-2561.

Brett, M. T. 1993. Comment on "Possibility of N or P limitation for planktonic cladocerans: An experimental test" (Urabe and Watanabe) and "Nutrient element limitation of zooplankton production: (Hessen). Limnol. Oceanogr. 38: 1333-1337.

Clemmesen, C. 1993. Improvements in the fluorimetric determination of the RNA and DNA content of individual marine fish larvae. Mar. Ecol. Prog. Ser. 100: 177-183.

- 1994. The effect of food availability, age or size on the RNA/DNA ratio of individually measured herring larvae: Laboratory calibration. Mar. Biol. 118: 377-382.

DeMott, W. R., R. D. Gulati, and K. Siewertsen. 1998. Effects of phosphorus-deficient diets on the carbon and phosphorus balance of Daphnia magna. Limnol. Oceanogr. 43: 1147-1161.

Elser, J. J., D. R. Dobberfuhl, N. A. Mackay, and J. H. Schampel. 1996. Organism size, life history, and $\mathrm{N}: \mathrm{P}$ stoichiometry. BioScience 46: 674-684.

Gismervik, I. 1997. Stoichiometry of some marine planktonic crustaceans. J. Plankton Res. 19: 279-285.

Grasshoff, K., K. Kremling, and M. Erhardt. 1999. Methods of seawater analysis, 3rd ed. Wiley-VCH.

Guillard, R., AND J. Ryther. 1962. Studies of marine planktonic diatoms. Can. J. Microbiol. 8: 229-239.

Hessen, D. O. 1992. Nutrient element limitation of zooplankton production. Am. Nat. 140: 799-814.

Hilton, G. M., R. W. Furness, and D. C. Houston. 2000. The effects of diet switching and mixing on digestion in seabirds. Funct. Ecol. 14: 145-154.

Hood, J. M., M. J. Vanni, and A. S. Flecker. 2005. Nutrient recycling by two phosphorus-rich grazing catfish: The potential for phosphorus-limitation of fish growth. Oecologia 146: 247.

Irigoien, X., K. J. Flynn, And R. P. Harris. 2005. Phytoplankton blooms: A 'loophole' in microzooplankton grazing impact? J. Plankton Res. 27: 313-321.

Izquierdo, M. S., J. Socorro, L. Arantzamendi, and C. M. Hernandez-Cruz. 2000. Recent advances in lipid nutrition in fish larvae. Fish Physiol. Biochem. 22: 97-107.

Klausmeier, C. A., E. Litchman, T. Daufresne, and S. A. Levin. 2004. Optimal nitrogen-to-phosphorus stoichiometry of phytoplankton. Nature 429: 171-174.

Lee, W. B., And D. C. Houston. 1993. The effect of diet quality on gut anatomy in British voles (Microtinae). J. Comp. Physiol. B V163: 337.

Le PecQ, J. B., And C. Paoletti. 1966. A new fluorometric method for RNA and DNA determination. Ann. Biochem. 17: 100-107.

Malzahn, A. M., M. Boersma, K. H. Wiltshire, C. Clemmesen, AND S. LAAKMANN. 2007. Comparative nutritional condition of larval dab and lesser sandeel in a highly variable environment. Mar. Ecol. Prog. Ser. 334: 205-212. 
C. Clemmesen, and H. Rosenthal. 2003. Temperature effects on growth and nucleic acids in laboratory-reared larval coregonid fish. Mar. Ecol. Prog. Ser. 259: 285-293.

Müller-Navarra, D. C. 1995. Biochemical versus mineral limitation in Daphnia. Limnol. Oceanogr. 40: 1209-1214.

Plath, K., and M. Boersma. 2001. Mineral limitation of zooplankton: Stoichiometric constraints and optimal foraging. Ecology 82: 1260-1269.

Raubenheimer, D., AND S. J. Simpson. 2003. Nutrient balancing in grasshoppers: Behavioural and physiological correlates of dietary breadth. J. Exp. Biol. 206: 1669-1681.

Sabat, P., J. A. Lagos, and F. Bozinovic. 1999. Test of the adaptive modulation hypothesis in rodents: Dietary flexibility and enzyme plasticity. Comp. Biochem. Phys. A 123: 83.

Sargent, J. R., and S. Falk-Petersen. 1988. The lipid biochemistry of calanoid copepods. Hydrobiologia 167/168: 101-114.

Schindler, D. E., AND L. A. EBy. 1997. Stoichiometry of fishes and their prey: Implications for nutrient recycling. Ecology 78: $1816-1831$.

Sterner, R. W. 1993. Daphnia growth on varying quality of Scenedesmus: Mineral limitation of zooplankton. Ecology 74: 2351-2360.

- AND J. J. Elser. 2002. Ecological stoichiometry: The biology of elements from molecules to the biosphere. Princeton University Press, Princeton, New Jersey.

-, And D. O. Hessen. 1994. Algal nutrient limitation and the nutrition of aquatic herbivores. Ann. Rev. Ecol. Sys. 25: 1-29.
St. John, M. A., C. Clemmesen, T. Lund, And T. Köster. 2001. Diatom production in the marine environment: Implications for larval fish growth and condition. ICES J. Mar. Sci. 58: 1106-1113.

Suneetha, K. B., A. Folkvord, and A. Johannessen. 1999. Responsiveness of selected condition measures of herring, Clupea harengus, larvae to starvation in relation to ontogeny and temperature. Environ. Biol. Fish. 54: 191-204.

Trier, T. M., And W. J. Mattson. 2003. Diet-induced thermogenesis in insects: A developing concept in nutritional ecology. Environ. Entomol. 32: 1-8.

Urabe, J., J. Clasen, and R. W. Sterner. 1997. Phosphorus limitation of Daphnia growth: Is it real? Limnol. Oceanogr. 42: 1436-1443.

Vielma, J., J. Koskela, and K. Ruohonen. 2002. Growth, bone mineralization, and heat and low oxygen tolerance in European whitefish (Coregonus lavaretus L.) fed with graded levels of phosphorus. Aquaculture 212: 321-333.

Zanotto, F. P., S. M. Gouveia, S. J. Simpson, D. Raubenheimer, AND P. C. CALDER. 1997. Nutritional homeostasis in locusts: Is there a mechanism for increased energy expenditure during carbohydrate overfeeding? J. Exp. Biol. 200: 2437-2448.

Received: 5 December 2006 Accepted: 18 April 2007 Amended: 2 May 2007 